\title{
BENEFICIAL EFFECTS OF LEVOTHYROXINE IN THE TREATMENT OF SUBCLINICAL HYPOTHYROIDISM
}

\author{
Mulic Mersudin, ${ }^{1}$ Halo Orhan, ${ }^{1}$ Skrijelj Fadil, ${ }^{1}$ Mulic Bilsana ${ }^{2}$ \\ ${ }^{1}$ State University of Novi Pazar, Novi Pazar; Serbia \\ ${ }^{2}$ General Hospital Novi Pazar; Novi Pazar; Serbia
}

Primljen/Received 12. 05. 2016. god.

Abstract: Introduction: Increased cardiovascular risk in thyroid dysfunction is associated with disorders of lipid and lipoproteins, endothelial dysfunction, metabolic, hormonal, hemodynamic changes and coagulation disorders.

Subclinical hypothyroidism is characterized by a supra normal level of TSH with normal levels of thyroid hormones. The correlation between subclinical hypothyroidism of the lipid profile and cardiovascular outcomes remains unclear. Several intervention studies assessed the effect of levothyroxine therapy on the lipid profile of patients with subclinical hypothyroidism and obtained conflicting results.

The aim of the research is to determine whether subclinical hypothyroidism is associated with the atherogenic lipid profile and whether these changes are reversible after the introduction of the L-thyroxine replacement therapy.

Method: The study included 51 patients over 50 years of age with subclinical hypothyroidism. All the participants were subjected to an examination program which included a detailed anamnesis and physical examination; laboratory tests (total cholesterol, LDL cholesterol, HDL cholesterol, triglycerides, T3, T4, TSH). After eight weeks of levothyroxine therapy, the same laboratory parameters were determined in the patients.

Results: Subjects with subclinical hypothyroidism had high average values: TSH $(12.77+2.78 \mathrm{mIU} / \mathrm{ml})$, total cholesterol $(7.55 \pm 0.79 \mathrm{mmol} / \mathrm{l})$, LDL cholesterol $(5.03 \pm 0.61 \mathrm{mmol} / \mathrm{l})$, triglycerides $(2.48 \pm 1.01 \mathrm{mmol} / \mathrm{l})$; and the average value of HDL cholesterol was within reference values $(1.12 \pm 0.21 \mathrm{mmol} / \mathrm{l})$. After eight weeks of levothyroxine replacement therapy, there was a statistically significant reduction of average values $(\mathrm{p}<0.0001)$ : TSH $(3.83 \pm 1.33 \mathrm{mIU} / \mathrm{ml})$, total cholesterol $(6.28 \pm$ $0.96 \mathrm{mmol} / \mathrm{l})$, LDL cholesterol $(4.03 \pm 0.70 \mathrm{mmol} /$ $\mathrm{mmol} / \mathrm{l} \mathrm{l})$, triglycerides $(1.98 \pm 0.87 \mathrm{mmol} / \mathrm{l})$; and the
Prihvaćen/Accepted 03. 07. 2016. god.

average value of HDL cholesterol increased significantly $(\mathrm{p}<0.0001)(1.32 \pm 0.22 \mathrm{mmol} / \mathrm{l})$.

Conclusion: Subjects with subclinical hypothyroidism have the atherogenic lipid profile which is corrected after the levothyroxine treatment. Subclinical hypothyroidism can be considered a disorder that leads to increased cardiovascular risk.

Key words: subclinical hypothyroidism, levothyroxine, lipids, cardiovascular risk.

\section{INTRODUCTION}

The correlation between hypothyroidism, lipid disorders and coronary heart disease was observed as far back as 1960. Elevated levels of total cholesterol, LDL cholesterol and triglycerides as well as reduced levels of HDL cholesterol are classified in the group of risk factors for ischemic heart disease.

Subclinical hypothyroidism ( $\mathrm{SH}$ ) is defined by elevated levels of TSH in the serum with normal levels of thyroid hormone (1). Factors that lead to an increased risk of developing cardiovascular disease in subclinical hypothyroidism are not entirely clear but this correlation is partly associated with high blood pressure, atherogenic lipid and lipoprotein status, proinflammatory conditions, endothelial dysfunction and hypercoagulability (2-10).

Although in the last 20 years several studies have examined the association between subclinical hypothyroidism ( $\mathrm{SH}$ ) and lipid levels, the exact correlation between the SH lipid profile and cardiovascular outcomes remains unclear (3-5, 11-16).

Several intervention studies assessed the effect of levothyroxine therapy on the lipid profile of patients with subclinical hypothyroidism and obtained different results. $(7,8,11,17-22)$.

Different results obtained by the above-mentioned observational studies may be attributed to many rea- 
sons, such as different age of the observed subjects, ethnicity, gender, degree and duration of hypothyroidism.

\section{THE AIM OF THE RESEARCH}

The aim of the research is to determine whether subclinical hypothyroidism is associated with the atherogenic lipid profile and whether these changes are reversible after the introduction of the levothyroxine replacement therapy.

\section{METHODS}

The research included 51 subjects over 50 years of age with subclinical hypothyroidism.

The research was carried out according to the following protocol:

1. Signing of the informed consent. Before any study procedure, a patient was informed on study design, and upon reading the informed consent, he/she signed it.

2. Obtaining history data. History data were obtained by means of structured history questionnaire.

3. Physical examination.

4. Laboratory tests: biological samples were collected: 1 test-tube with citrate for SE, 1 test-tube containing EDTA $(5 \mathrm{ml})$ for complete blood count, 2 test tubes for serum separation $(10 \mathrm{ml}$ each) for biochemical analyses (cholesterol, triglycerides, LDL cholesterol, HDL cholesterol) and immune-metric analyses (T3, T4, TSH).

The study included patients who met all the inclusion criteria and had none of exclusion criteria.

Inclusion criteria were as follows:

1. The informed consent signed

2. The patients over 50 years of age

3 . Each of them diagnosed with subclinical hypothyroidism.

Exclusion criteria:

1. Evidence on acute infection in the last 2 weeks.

2. Positive bio-humoral inflammatory syndrome (accelerated SE and leukocytosis).

3. Use of medicaments that may interfere with studied parameters (glucocorticoids, iodine preparations, amiodarone, diuretics, lithium, cytostatics, anti-depressives, estrogens, androgens).

4. Chronic diseases that may have effect on studied parameters (systemic autoimmune diseases, malignant diseases, chronic renal failure, liver insufficiency, acute cardiovascular and cerebrovascular insults and insults within the last 6 months).

5. Recent use of radioactive iodine, surgical interventions of thyroid gland and external neck radiation.

6. Pregnancy and breast feeding.
The initial study phase involved the collection of history data and thorough physical examination. Blood samples collected after 12-hour fasting were used for the following measurements: cholesterol, triglycerides, LDL cholesterol, HDL cholesterol (colorimetric method based on end-point principle). TSH was determined by immunochemical method - chemiluminescent procedure including chemiluminescent substrate. The method was automated (IMMULITE $®$ DPC). Reference values: TSH: $0.27-4.20 \mathrm{mIU} / \mathrm{ml}$; Variation coefficient: $5.50 \%$.

$\mathrm{T} 3$ is done on the principle of a competitive immunoassay by a 30 -minute incubation, analytical sensitivity of $0.54 \mathrm{nmol} / \mathrm{L}$, and measurement range of 0.61 to $9.2 \mathrm{nmol} / \mathrm{L}$; Reference values: $1: 10$ to $3: 10 \mathrm{nmol} / 1$.

T4 is done on the principle of a competitive immunoassay by a 30 -minute incubation, analytical sensitivity of $5 \mathrm{nmol} / \mathrm{L}$, and measurement range of 13 to $309 \mathrm{nmol} / \mathrm{L}$; Reference values: $58-161 \mathrm{nmol} / \mathrm{l}$.

After eight weeks of levothyroxine treatment the same laboratory parameters were determined in patients.

Group formation: The decision criterion for the placement of patients in the group with subclinical hypothyroidism was TSH value: $>4.2 \mathrm{IU} / \mathrm{mL}$, and patients were divided according to age group: 18 patients aged 50 to 55,17 patients aged 56 to 60 and 16 patients aged over 60 .

Before beginning a statistical analysis, laboratory reports with the results of the analyses of patients were anonymised and granted a research code (to protect the privacy of patients, the code is known only to the researcher). An electronic database was created in the SPSS version 20.0. The mean value, standard deviation (SD), median, minimum and maximum values were determined. Univariate methods were used in testing significance of differences: $\chi^{2}$ test, Student's t-test. Rank correlation was used to test parallelism. The $p$ value of $<0.05$ is statisticaly significant, with the calculation of $95 \%$ confidence interval.

\section{RESULTS}

The study included 51 subjects over 50 years of age with subclinical hypothyroidism.

The average age of patients was $58.32 \pm 5.80$. Statistically, in gender representation, there were significantly more female patients, i.e. there were 42 female $(82.35 \%)$ and 9 male patients, or $17.65 \%$, for $\chi^{2}=11.842$, $\mathrm{p}<0.001$.

The average values of $\mathrm{T} 3$ and $\mathrm{T} 4$ before and after eight weeks levothyroxine therapy remained within reference values (Table 1). 
Table 1. Average values of T3 and T4 in relation to the age of the patients before and after treatment

\begin{tabular}{|c|c|c|c|c|c|c|c|c|}
\hline \multirow{2}{*}{\multicolumn{2}{|c|}{ Age - intervals }} & \multicolumn{3}{|c|}{ Before treatment } & \multirow{2}{*}{ F test } & \multicolumn{2}{|c|}{ After treatment } & \multirow{2}{*}{ F test } \\
\hline & & $\mathrm{N}$ & Average & SD & & Average & SD & \\
\hline \multirow{4}{*}{$\begin{array}{c}\mathrm{T} 4 \\
\mathrm{nmol} / \mathrm{l}\end{array}$} & Up to 55 & 18 & 103.15 & 21.78 & \multirow{4}{*}{$\begin{array}{c}\mathrm{F}=2.413 \\
\mathrm{p}<0,05\end{array}$} & 128.63 & 25.4 & \multirow{4}{*}{$\begin{array}{c}\mathrm{F}=3.113 \\
\mathrm{p}<0,05\end{array}$} \\
\hline & 56 to 60 & 17 & 85.00 & 20.32 & & 106 & 25.92 & \\
\hline & Over 60 & 16 & 99.88 & 18.95 & & 114.98 & 20.69 & \\
\hline & Total & 51 & 96.56 & 21.11 & & 117.89 & 25.17 & \\
\hline \multirow{4}{*}{$\begin{array}{c}\mathrm{T} 3 \\
\mathrm{nmol} / 1\end{array}$} & Up to 55 & 18 & 1.93 & 0.51 & \multirow{4}{*}{$\begin{array}{c}\mathrm{F}=0.046 \\
\mathrm{p}=\mathrm{ns}\end{array}$} & 2.44 & 0.44 & \multirow{4}{*}{$\begin{array}{c}\mathrm{F}=0.321 \\
\mathrm{p}=\mathrm{ns}\end{array}$} \\
\hline & 56 to 60 & 17 & 1.87 & 0.67 & & 2.64 & 0.53 & \\
\hline & Over 60 & 16 & 1.84 & 0.25 & & 2.16 & 0.4 & \\
\hline & Total & 51 & 1.88 & 0.49 & & 2.43 & 0.47 & \\
\hline
\end{tabular}

T3- triiodothyronine; T4 - thyroxine;

Average values of TSH in all age groups were reduced after eight weeks of levothyroxine treatment (Table 2).

Table 2. Average values of TSH in relation to the age of the patients before and after treatment

\begin{tabular}{|c|c|c|c|c|c|c|c|c|}
\hline \multirow{2}{*}{\multicolumn{2}{|c|}{ Age - intervals }} & \multicolumn{3}{|c|}{ Before treatment } & \multirow{2}{*}{ F test } & \multicolumn{2}{|c|}{ After treatment } & \multirow{2}{*}{$\mathrm{F}$ test } \\
\hline & & $\mathrm{N}$ & Average & $\mathrm{SD}$ & & Average & $\mathrm{SD}$ & \\
\hline \multirow{4}{*}{$\begin{array}{c}\mathrm{TSH} \\
\mathrm{mIU} / \mathrm{ml}\end{array}$} & Up to 55 & 18 & 12.60 & 3.67 & \multirow{4}{*}{$\begin{array}{c}\mathrm{F}=0.457 \\
\mathrm{p}=\mathrm{ns}\end{array}$} & 3.65 & 2.2 & \multirow{4}{*}{$\begin{array}{c}\mathrm{F}=1.591 \\
\mathrm{p}=\mathrm{ns}\end{array}$} \\
\hline & 56 to 60 & 17 & 12.00 & 1.69 & & 3.72 & 0.45 & \\
\hline & Over 60 & 16 & 13.72 & 2.98 & & 4.12 & 1.35 & \\
\hline & Total & 51 & 12.77 & 2.78 & & 3.83 & 1.33 & \\
\hline
\end{tabular}

TSH: thyroid stimulating hormone

Average values of lipids by age group before and after treatment are given in Table 3 .

Table 3. Average values of lipids before and after treatment in relation to the age group of patients

\begin{tabular}{|c|c|c|c|c|c|c|c|c|}
\hline \multirow{2}{*}{\multicolumn{2}{|c|}{ Age - intervals }} & \multicolumn{3}{|c|}{ Before treatment } & \multirow{2}{*}{ F test } & \multicolumn{2}{|c|}{ After treatment } & \multirow{2}{*}{ F test } \\
\hline & & $\mathrm{N}$ & Average & $\mathrm{SD}$ & & Average & $\mathrm{SD}$ & \\
\hline \multirow{4}{*}{$\begin{array}{c}\text { Cholesterol } \\
\mathrm{mmol} / \mathrm{l}\end{array}$} & Up to 55 & 18 & 7.13 & 0.61 & \multirow{4}{*}{$\begin{array}{c}\mathrm{F}=1.539 \\
\mathrm{p}=\mathrm{ns}\end{array}$} & 6.06 & 1.15 & \multirow{4}{*}{$\begin{array}{c}\mathrm{F}=0.339 \\
\mathrm{p}=\mathrm{ns}\end{array}$} \\
\hline & 56 to 60 & 17 & 7.73 & 0.67 & & 6.38 & 0.46 & \\
\hline & Over 60 & 16 & 7.80 & 1.10 & & 6.39 & 1.27 & \\
\hline & Total & 51 & 7.55 & 0.79 & & 6.28 & 0.96 & \\
\hline \multirow{4}{*}{$\begin{array}{c}\text { Triglycerides } \\
\mathrm{mmol} / \mathrm{l}\end{array}$} & Up to 55 & 18 & 2.15 & 0.64 & \multirow{4}{*}{$\begin{array}{c}\mathrm{F}=0.643 \\
\mathrm{p}=\mathrm{ns}\end{array}$} & 1.94 & 0.62 & \multirow{4}{*}{$\begin{array}{c}\mathrm{F}=0.561 \\
\mathrm{p}=\mathrm{ns}\end{array}$} \\
\hline & 56 to 60 & 17 & 2.55 & 1.13 & & 2.08 & 0.97 & \\
\hline & Over 60 & 16 & 2.75 & 1.26 & & 1.91 & 1.01 & \\
\hline & Total & 51 & 2.48 & 1.01 & & 1.98 & 0.87 & \\
\hline \multirow{4}{*}{$\begin{array}{l}\text { LDL-ch } \\
\mathrm{mmol} / 1\end{array}$} & Up to 55 & 18 & 4.60 & 0.56 & \multirow{4}{*}{$\begin{array}{c}F=3.726 \\
p<0,05\end{array}$} & 3.87 & 0.59 & \multirow{4}{*}{$\begin{array}{c}\mathrm{F}=0.299 \\
\mathrm{p}=\mathrm{ns}\end{array}$} \\
\hline & 56 to 60 & 17 & 5.03 & 0.72 & & 4.10 & 0.53 & \\
\hline & Over 60 & 16 & 5.47 & 0.57 & & 4.14 & 0.99 & \\
\hline & Total & 51 & 5.03 & 0.61 & & 4.03 & 0.7 & \\
\hline \multirow{4}{*}{$\begin{array}{l}\text { HDL-ch } \\
\mathrm{mmol} / \mathrm{l}\end{array}$} & to 55 & 18 & 1.19 & 0.25 & \multirow{4}{*}{$\begin{array}{c}\mathrm{F}=0.446 \\
\mathrm{p}=\mathrm{ns}\end{array}$} & 1.38 & 0.21 & \multirow{4}{*}{$\begin{array}{c}\mathrm{F}=0.769 \\
\mathrm{p}=\mathrm{ns}\end{array}$} \\
\hline & 56 to 60 & 17 & 1.08 & 0.18 & & 1.37 & 0.24 & \\
\hline & Over 60 & 16 & 1.11 & 0.22 & & 1.23 & 0.22 & \\
\hline & Total & 51 & 1.12 & 0.21 & & 1.32 & 0.22 & \\
\hline
\end{tabular}


Table 4. PAIRED T TEST- total all patients

\begin{tabular}{|c|c|c|c|c|c|}
\hline $\begin{array}{c}\text { Total patients } \\
\text { Before/after }\end{array}$ & Correlation & Sig. & $\mathbf{t}$ & df & $\begin{array}{c}\text { Sig. } \\
\text { (2-tailed) }\end{array}$ \\
\hline T4 v.s. T4 control measurement & 0.876 & $0.001^{* * *}$ & -7.633 & 18 & $0.0001^{* * *}$ \\
\hline T3 v.s. T3 control measurement & 0.711 & $0.001 * * *$ & -6.448 & 18 & $0.0001^{* * *}$ \\
\hline TSH v.s. TSH control measurement & 0.650 & $0.001 * * *$ & 17.374 & 18 & $0.0001^{* * *}$ \\
\hline Cholesterol vs. Chol. control measurement & 0.715 & $0.001^{* * *}$ & 7.841 & 18 & $0.0001^{* * *}$ \\
\hline Triglycerides vs. Triglycerides control measurement & -0.564 & $0.01 * *$ & 9.988 & 18 & $0.0001^{* * *}$ \\
\hline LDL-ch vs. LDL-ch control measurement & 0.640 & $0.003^{* *}$ & 7,174 & 18 & $0.0001^{* * *}$ \\
\hline HDL-ch vs. HDL-ch control measurement & -0.734 & $0.001^{* * *}$ & $-5,536$ & 18 & $0.0001^{* * *}$ \\
\hline
\end{tabular}

The average values of total cholesterol, triglycerides and HDL cholesterol did not, statistically speaking, significantly differ among age groups either before or after treatment $(\mathrm{p}=\mathrm{ns})$.

The average value of LDL cholesterol before treatment was significantly different among age groups ( $p$ $<0.05$ ), but after treatment the average value of LDL cholesterol was not significantly different among age groups $(\mathrm{p}=\mathrm{ns})$.

The results of correlation and the paired Student's $\mathrm{T}$ test before and after treatment are shown in Table 4.

The analysis of the values of TSH, total cholesterol, LDL cholesterol and triglycerides before and after treatment showed a highly significant direct correlation, and the paired $\mathrm{T}$ test showed that the values of $\mathrm{TSH}$, total cholesterol, LDL cholesterol and triglyceride levels significantly decreased after the patients received treatment, total $(\mathrm{p}<0.0001)$.

The analysis of the value of HDL cholesterol before and after treatment showed a highly significant inverse correlation, and the paired $\mathrm{T}$ test showed that the value of HDL cholesterol increased after the patients received treatment in total, statistically significant $(\mathrm{p}<0.0001)$.

\section{DISCUSSION}

This study shows that in patients with SH there was the atherogenic lipid profile, which was corrected significantly after the application of levothyroxine. The results of this study suggest that the levothyroxine replacement in the examined groups (aged over 50 and with an average TSH $>10 \mathrm{mIU} / \mathrm{ml}$ ) is completely justified.

Subclinical hypothyroidism is defined by elevated levels of TSH in the serum with normal levels of thyroid hormones. Patients with subclinical thyroid dysfunction are not identified on the basis of signs and symptoms even when they are discreetly present. A typical population-based study in the district of Whickham in England found the prevalence of 75 per 1000 women and 28 per 1000 men (23); similar findings are presented in other studies (24). A higher incidence of subclinical hypothyroidism in women than in men and in the older age group than in the younger one is parallel to the higher incidence of thyroperoxidase and thyroglobulin antibodies in women and the elderly $(25$, 26). In our study, of the 51 patients with $\mathrm{SH}, 42(82.35 \%)$ were women.

A disturbed lipid profile is a well-known manifestation of thyroid dysfunction. Results from observational studies that followed the level of serum lipids in patients with subclinical hypothyroidism are inconsistent $(1,4,5)$. A large epidemiological study showed a positive correlation between serum TSH and dyslipidemia, and also showed that subclinical hypothyroidism is an intermediate state between euthyroid and clinical hypothyroidism when it comes to lipid profiles (27). In the Colorado study from 2000 which was carried out on 25862 participants, Canaris et al. found that people with impaired thyroid function in terms of subclinical hypothyroidism have significantly higher levels of total cholesterol, LDL-cholesterol and triglycerides (27). In the Busselton study from 2002, Walsh et al. on a sample of 2108 Australian participants found that TSH is positively correlated with total cholesterol, triglycerides, LDL-cholesterol (12). EPIC-Norfolk prospective study showed a statistically significant increase in the concentration of total cholesterol, LDL cholesterol and triglyceride levels only in women with subclinical hypothyroidism (28). In 2011, Lai et al. among 1534 Chinese adults found that people with subclinical hypothyroidism have higher levels of triglycerides and low HDL cholesterol compared to euthyroid people (15). There are studies that show different results. In 2004, Hueston et al. processed data about 8,586 adult subjects from the The National Health and Nutrition Examination Survey III database and concluded that subclinical hypothyroidism is not associated with the disorder of the levels of total cholesterol, LDL cholesterol, triglycerides and HDL cholesterol (29). In our study subjects with subclinical hypothyroidism had 
significantly higher levels of total and LDL cholesterol before the introduction of L-thyroxine as compared to the results obtained eight weeks after its replacement. Triglyceride levels were significantly higher in patients with subclinical hypothyroidism before treatment compared to the results after treatment. In the group of subjects with subclinical hypothyroidism HDL was within reference values and after levothyroxine therapy its value was increased. Our study established a direct correlation between $\mathrm{TSH}$ and the levels of total and LDL cholesterol.

Several intervention studies assessed the effect of levothyroxine therapy on the lipid profile of patients with subclinical hypothyroidism and obtained different results $(20-22,26)$. Tzotzas et al. found that the lipid profile of patients with subclinical hypothyroidism does not differ from euthyroid controls and that levothyroxine therapy does not lead to significant changes in lipid levels (30). Razvi et al. carried out a randomized, double-blind study, and after 12 weeks of levothyroxine treatment the patients had significantly lower levels of total and LDL cholesterol, while there was no significant effect on HDL cholesterol and triglycerides (8). Most studies show a beneficial effect of levothyroxine treatment with basal TSH values above $10 \mathrm{mIU} / \mathrm{l}(20,31)$. This was confirmed in the subjects observed in our study. In our study, the average value of TSH before treatment was $12.71 \mathrm{mIU} / 1$. These results are consistent with our results. It is believed that higher TSH levels $(>10 \mathrm{mi} / \mathrm{l})$ are associated with the at- herogenic LDL cholesterol fraction and increased cardiovascular risk $(20,32)$.

In conclusion we can say that the results of this study suggest that subjects with subclinical hypothyroidism have the atherogenic lipid profile which is corrected after levothyroxine treatment and that subclinical hypothyroidism can be considered a disorder that leads to increased cardiovascular risk. In assessing the introduction of levothyroxine therapy in these patients, in addition to the determination of serum TSH levels, an individual cardiovascular risk should be determined, which is essential in making decisions about the treatment of these patients.

\section{Conflict of interest}

Authors confirmed that no actual or potential conflict of interest exists in relation to this article.

\section{Source of Funding}

There were no external funding source for this study.
Abbreviations
TSH - thyroid stimulating hormone
T3 - triiodothyronine
T4 - thyroxine;
LDL - Low density lipoproteins
HDL - High density lipoproteins s
SH - ubclinical hypothyroidism

\title{
Sažetak
}

\section{KORISTAN EFEKAT LEVOTIROKSINA U TRETMANU SUBKLINIČKE HIPOTIREOZE}

\author{
Mulić Mersudin, ${ }^{1}$ Halo Orhan, ${ }^{1}$ Škrijelj Fadil, ${ }^{1}$ Mulić Bilsana ${ }^{2}$ \\ ${ }^{1}$ State University of Novi Pazar, Novi Pazar; Serbia \\ ${ }^{2}$ General Hospital Novi Pazar; Novi Pazar; Serbia
}

Uvod: Povećan kardiovaskularni rizik u disfunkciji štitaste žlezde u vezi je sa poremećajima metabolizma lipida i lipoproteina, endotelijalnom disfunkcijom, metaboličkim, hormonskim, hemodinamskim promenama i poremećajima koagulacije.

Subklinička hipotireoza karakteriše se supranormalnim nivoom TSH uz normalne vrednosti tireoidnih hormona. Udruženost subkliničkog hipotireoidizma lipidnog statusa i kardiovaskularnog ishoda je i dalje nejasna.Više interventnih studija je ocenjivalo efekat terapije levotiroksinom na lipidni profil pacijenata sa subkliničkom hipotireozom i dobijeni su konfliktni rezultati.

Cilj ispitivanja je da se utvrdi da li je subklinička hipotireoza udružena sa aterogenim lipidnim profilom i da li su ove promene reverzibilne nakon uvođenja supstitucione terapije levotiroksinom.

Metod: Istraživanjem je obuhvaćen 51 ispitanik uzrasta iznad 50 godina sa subkliničkom hipotireozom. Kod svih ispitanika sproveden je program istraživanja koji uključuje: detaljnu anamnezu i fizikalni pregled, laboratorijska ispitivanja (ukupni holesterol, LDL holesterol, HDL holesterol, trigliceridi, T3, T4, TSH). Nakon osmonedeljne terapije levotiroksinom kod bolesnika su određivani isti laboratorijski parametri.

Rezultati: ispitanici sa subkliničkom hipotireozom imali su povišene prosečne vrednosti: TSH (12.77 $\pm 2.78 \mathrm{mIU} / \mathrm{ml})$, ukupnog holesterola $(7.55 \pm 0.79$ 
$\mathrm{mmol} / \mathrm{l})$, LDL holesterola $(5.03 \pm 0.61 \mathrm{mmol} / \mathrm{l})$, triglicerida $(2.48 \pm 1.01 \mathrm{mmol} / \mathrm{l})$; a prosečna vrednost HDL holesterola bila je u referentnim vrednostima (1.12 \pm 0.21 $\mathrm{mmol} / \mathrm{l}$ ). Nakon osmonedeljne supstitucije levotiroksinom kod ovih ispitanika dolazi do, statistički značajnog, sniženja prosečnih vrednosti ( $\mathrm{p}<0,0001)$ : TSH $(3.83 \pm$ $1.33 \mathrm{mIU} / \mathrm{ml})$, ukupnog holesterola $(6.28 \pm 0.96 \mathrm{mmol} / \mathrm{l})$, LDL holesterola $(4.03 \pm 0.70 \mathrm{mmol} / \mathrm{lmmol} / \mathrm{l})$, triglicerida $(1.98 \pm 0.87 \mathrm{mmol} / \mathrm{l})$; a prosečna vrednost HDL hole-

\section{REFERENCE}

1. Cooper DS, Biondi B. Subclinical thyroid disease. Lancet. 2012; 379 (9821): 1142-54.

2. Ye Y, Xie H, Zeng Y, Zhao X, Tian Z, Zhang S. Association between subclinical hypothyroidism and blood pressure: a meta-analysis of observational studies. Endocr Pract. 2014; 20(2): 150-8.

3. Neves C, Alves M, Medina JL, Delgado JL. Thyroid diseases, dyslipidemia and cardiovascular pathology. Rev Port Cardiol. 2008; 27(10): 1211-36.

4. Pearce EN. Update in lipid alterations in subclinical hypothyroidism. J Clin Endocrinol Metab. 2012; 97(2): 326-33.

5. Liu XL, He S, Zhang SF, et al. Alteration of lipid profile in subclinical hypothyroidism: a meta-analysis. Med Sci Monit. 2014; 20: 1432-41.

5. Park YJ, Lee YJ, Choi SI, Chun EJ, Jang HC, Chang HJ. Impact of subclinical hypothyroidism on the coronary artery disease in apparently healthy subjects. Eur J Endocrinol. 2011; 165(1): 115-21.

7. Marfella R, Ferraraccio F, Rizzo MR, et al. Innate immune activity in plaque of patients with untreated and L-thyroxine-treated subclinical hypothyroidism. J Clin Endocrinol Metab.2011; 96(4): 1015-20.

8. Razvi S, Ingoe L, Keeka G, Oates C, McMillan C, Weaver JU. The beneficial effect of L-thyroxine on cardiovascular risk factors, endothelial function, and quality of life in subclinical hypothyroidism: randomized, crossover trial. J Clin Endocrinol Metab. 2007; 92(5): 1715-23.

9. Biondi B, Cooper DS. The clinical significance of subclinical thyroid dysfunction. Endocr Rev. 2008; 29(1): 76-131.

10. Taylor PN, Razvi S, Pearce SH, Dayan CM. Clinical review: a review of the clinical consequences of variation in thyroid function within the reference range. J Clin Endocrinol Metab. 2013; 98(9): 3562-71.

11. Caraccio N, Ferranini E, Monzani F. Lipoprotein profile in subclinical hypothyroidism: response to levothyroxine replacement, a randomized placebo-controlled study. J Clin Endocrinol Metab. 2002; 87(4): 1533-8.

12. Walsh JP, Bremner AP, Bulsara MK, et al. Thyroid dysfunction and serum lipids: a community-based study. Clin Endocrinol (Oxf). 2005; 63(6): 670-5.

13. Kvetny J, Heldgaard PE, Bladbjerg EM, Gram J. Subclinical hypothyroidism is associated with a low-grade inflammation, increased triglyceride levels and predicts cardiovascular disease in males below 50 years. Clin Endocrinol (Oxf). 2004; 61(2): 232-8. sterola je, statistički značajno, porasla ( $p<0,0001)$ : $(1.32 \pm 0.22 \mathrm{mmol} / \mathrm{l})$.

Zaključak: Ispitanici sa subkliničkom hipotireozom imaju aterogeni lipidni profil koji se koriguje nakon tretmana levotiroksinom. Subklinička hipotireoza može se smatrati poremećajem koji vodi povećanom kardiovaskularnom riziku.

Ključne reči: subklinička hipotireoza, levotiroksin, lipidi, kardiovaskularni rizik.

14. Rodondi N, den Elzen WP, Bauer DC,et al. Subclinical hypothyroidism and the risk of coronary heart disease and mortality. JAMA. 2010; 304(12): 1365-74.

15. Lai Y, Wang J, Jiang F, et al. The relationship between serum thyrotropin and components of metabolic syndrome. Endocr J. 2011; 58(1): 23-30.

16. Lee ZK, Kim JE, Oh HJ et al. Serum TSH level in healthy Koreans and the association of TSH with serum lipid concentration and metabolic syndrome. Korean J Intern Med 2011; 26(4): 432-9.

17. Meier C, Staub JJ, Roth CB. et al. TSH-controlled L-thyroxine therapy reduces cholesterol levels and clinical symptoms in subclinical hypothyroidism: a double-blind, placebo-controlled trial (Basel Thyroid Study). J Clin Endocrinol Metab 2001; 86(10): 4860-6.

18. Kong WM, Sheikh MH, Lumb PJ, et al. A 6-month randomized trial of thyroxine treatment in women with mild subclinical hypothyroidism. Am J Med. 2002; 112(5): 348-54.

19. Adrees M, Gibney J, El-Saeity N, Boran G. Effects of 18 months of L-T4 replacement in women with subclinical hypothyroidism. Clin Endocrinol (Oxf). 2009; 71(2): 298-303.

20. Lioudaki E, Mavroeidi NG, Mikhailidis DP, Ganotakis ES. Subclinical hypothyroidism and vascular risk: an update. Hormones. 2013; 12(4): 495-506.

21. Madathil A, Hollingsworth KG, Blamire AM, et al. Levothyroxine improves abnormal cardiac bioenergetics in subclinical hypothyroidism: a cardiac magnetic resonance spectroscopic study. J Clin Endocrinol Metab 2015; 100(4): E607-10.

22. Javed Z, Sathyapalan T. Levothyroxine treatment of mild subclinical hypothyroidism: a review of potential risks and benefits. Ther Adv Endocrinol Metab. 2016; 7(1): 12-23.

23. Vanderïumï MP, Tunbridge WM, French JM, et al. The incidence of thvroid disorders in the community: a twenty-year follow-uï of the Whickham Survey. Clin. Endocrinol. 1995; 43(1): 55-68.

24. Kim YA, Park YJ. Prevalence and risk factors of subclinical thyroid disease. Endocrinol Metab (Seoul). 2014; 29(1): 20-9.

25. Pearce SH, Brabant G, Duntas LH et al. 2013 ETA Guideline: Management of subclinical hypothyroidism. Eur Thyroid J. 2013; 2(4): 215-28.

26. Baumgartner C, Blum MR, Rodondi N. Subclinical hypothyroidism: summary of evidence in 2014. Swiss Med Wkly. 2014; 144: w14058.

27. Canaris GJ, Manowitz NR, Mayor G, Ridgway EC. The Colorado thyroid disease prevalence study. Arch Intern Med. 2000; 160(4): 526-34.

28. Boekholdt SM, Titan SM, Wiersinga WM et al. Initial thyroid status and cardiovascular risk factors: the EPIC-Norfolk 
prospective population study. Clin Endocrinol (Oxf). 2010; 72(3): 404-10.

29. Hueston WJ, Pearson WS. Subclinical hypothyroidism and the risk of hypercholesterolemia. Ann fam Med 2004; 2(4): 351-5.

30. Tzotzas T, Krassas GE, Konstantinidis T, Bougoulia M. Changes in lipoprotein(a) levels in overt and subclinical hypothyroidism before and during treatment. Thyroid. 2000; 10(9): 803-8.

\section{Correspondence to / Autor za korespondenciju}

Mersudin Mulić, MD, PhD, internist-endocrinologist

State University of Novi Pazar, Novi Pazar, Serbia

"Sutjeska" C/11. 36300, Novi Pazar, Serbia

Phone: + 38163661373

e-mail: emmulic@mts.rs
31. Duntas LH, Mantzou E, Koutras DA. Circulating levels of oxidized low-density lipoprotein in overt and mild hypothyroidism. Thyroid. 2002; 12(11): 1003-7.

32. Brenta G, Berg G, Arias P et al. Lipoprotein alterations, hepatic lipase activity, and insulin sensitivity in subclinical hypothyroidism: response to L-T4 treatment. Thyroid. 2007; 17(5): 453-60. 